\title{
What Does Career and Personal Success Look Like? Engineering Students' Projections for Post-Graduation Plans
}

\author{
Mr. Aisosa Ayela-Uwangue, Arizona State University \\ Dr. Micah Lande, Arizona State University
}

Micah Lande, Ph.D. is an Assistant Professor in the Engineering and Manufacturing Engineering programs and Tooker Professor at the Polytechnic School in the Ira A. Fulton Schools of Engineering at Arizona State University. He teaches human-centered engineering design, design thinking, and design innovation project courses. Dr. Lande researches how technical and non-technical people learn and apply a design process to their work. He is interested in the intersection of designerly epistemic identities and vocational pathways. Dr. Lande is the PI/co-PI on NSF-funded projects focused on engineering doing and making, citizen science and engineering outreach, and "revolutionizing" engineering education. He has also been an instructor and participant in the NSF Innovation Corps for Learning program. He received his B.S in Engineering (Product Design), M.A. in Education (Learning, Design and Technology) and Ph.D. in Mechanical Engineering (Design Education) from Stanford University. 


\section{What Does Career and Personal Success Look Like? Engineering Students' Projections for Post-Graduation Plans}

\section{Introduction}

The undergraduate engineering degree continues to be the gateway for recruiting engineers into the engineering profession. Colleges, universities and corporations have dedicated a lot of resources over the years towards recruiting students into engineering majors, with the hope that once students successfully complete their undergraduate degree programs, they are likely to pursue careers in engineering. Recent statistics from the NSF has shown that the inflow into engineering majors and the outflow of graduates into engineering careers lags significantly behind other professional degrees. A possible reason for this is that the engineering degree provides a wide range of opportunities for graduating students to pursue and achieve their perceived success.

This is a Research Paper and Evidence-Based Practice Paper to explore how graduating undergraduate engineering students conceive of career and personal success. Through a qualitative review of "vision plans" students create to map to their first 5 to 10 years postgraduation plans, we have categorized areas for success that include themes of production, experience, character and relationships. Through in-class exercises in a senior year (noncapstone) course on professional orientation and a freshmen class orienting students to college, 30 students used exercises and assignments that have them use design thinking, networking, and informational interviews to better identify and understand possible vocational pathways. A culminating activity is for them to imagine and report not just one possible career option but multiple possible parallel pathways through a "vision plan" through the 5-10 years after graduation. By way of these "vision plans" created by students, we have begun to better understand students' perception of success and how this perception influences their initial career decisions.

We aim to be able to present a multiplicity of ways students consider career and personal success. These are questions that students, engineers, universities and corporations grapple with in preparing, recruiting and supervising aspiring and practicing engineers. Students' identity of success in their career choice continues to evolve as they transition through various stages of their undergraduate years, complete their undergraduate degree programs, and begin their careers in industry. This qualitative study explores what students consider to be success and how this may shape their future career pathways.

\section{Literature Review}

\section{Career Orientation and Structural Planning}

Engineering education is usually considered pre-professional preparation. Universities are invested in the future success of their students and usually have career centers and career preparation support. Resources can be made available from career focus through individual skill 
exploration to the mechanics of job finding with career fairs, resume preparation and job interview coordination (Lent, 2013). Of note, these activities generally happen outside of a traditional course.

\section{Vocational Pathways and Motivation}

The possible pathways for undergraduate engineering students has been studied. In particular, findings from the Center on the Advancement of Engineering Education's Academic Pathways Study (Atman et al., 2010), studying undergraduate persistence in engineering and students' pathway by and through engineering studies, found 2 groups of students with different motivations for engagement. The first seeks financial security, overcoming barriers of foundational math and science courses to continue, aiming for graduation. The second approached their studies with an intrinsic psychological motivation, seeking meaning and impact through their studies. These differing world views can oftentimes be either amplified or lessened by the approach taken in career preparation by the institution's career center and its focus.

\section{Engineering and Adulting}

There is a growing body of literature focused on the developmental stage immediately after college as one of "emerging adulthood" (Arnett, 2000) or "adulting" (Oishi, 2012). Oishi (2012), in particular, has combined Bandura's self-agency (1989) into "career development agency" (Oishi, 2012) and studied interventions around "design thinking" (Brown, 2008) to mitigate "career uncertainty" (Oishi, 2012). Through the context of a course called Designing Your Life (Burnett and Evans, 2011), scholars have examined activities related to vision plans, or life mapping (Oishi, 2012; Reilly, 2013). Burnett and Evans (2016) have developed this activity as part of a course for undergraduate and graduate students. (The second author has participated in these class as a section facilitator.) The Odyssey Plan activity is adapted from this course.

\section{Research Design}

This study was guided by the research question:

- How do undergraduate engineering students project their conceptions of what personal and professional success may look like?

To guide the research design, Crotty's four elements of a research study was used. Detailed in Table 1, the rationale explains how the theories and methodologies come together to build the methods in which the study was conducted. 
Table 1: Elements of a Research Study (Crotty 2012)

\begin{tabular}{|l|l|l|l|}
\hline & Definition & Selected & Rationale \\
\hline Epistemology & Theory of knowledge & $\begin{array}{l}\text { Constructivism } \\
\text { Knowledge is } \\
\text { constructed through } \\
\text { human-world } \\
\text { interaction (Piaget, } \\
1967)\end{array}$ & $\begin{array}{l}\text { To understand how } \\
\text { students project their } \\
\text { career and vocational } \\
\text { vision }\end{array}$ \\
\hline $\begin{array}{l}\text { Theoretical } \\
\text { Perspective }\end{array}$ & $\begin{array}{l}\text { Philosophy that } \\
\text { informs methodology }\end{array}$ & $\begin{array}{l}\text { Constructionism } \\
\text { Meaning is created } \\
\text { through constructing } \\
\text { and sharing artifacts } \\
\text { (Papert, 1991) }\end{array}$ & $\begin{array}{l}\text { To understand how } \\
\text { students imagine their } \\
\text { career and vocational } \\
\text { future }\end{array}$ \\
\hline Methodology & $\begin{array}{l}\text { Design connecting } \\
\text { methods to outcomes }\end{array}$ & $\begin{array}{l}\text { Constructivist } \\
\text { Grounded Theory } \\
\text { Researcher is the } \\
\text { author of } \\
\text { participant's voice } \\
\text { and meaning } \\
\text { (Charmaz, 2000, } \\
\text { 2006) }\end{array}$ & $\begin{array}{l}\text { To account for } \\
\text { context of student } \\
\text { sharing of odyssey } \\
\text { plans }\end{array}$ \\
& $\begin{array}{l}\text { Implementation of } \\
\text { methodology }\end{array}$ & $\begin{array}{l}\text { Student constructions } \\
\text { of their career and } \\
\text { vocational futures } \\
\text { through presenting } \\
\text { their odyssey plans }\end{array}$ & $\begin{array}{l}\text { To understand } \\
\text { student sharing of } \\
\text { their odyssey plans }\end{array}$ \\
\hline Methods & &
\end{tabular}

\section{Research Methodologies and Data Collection}

Student odyssey plan presentations were audio recorded and transcribed. A close document analysis of the transcriptions were then subjected to an emergent, qualitative thematic analysis (Braun \& Clarke, 2006) to draw meaning from the multiple plans generated from students.

We developed a coding scheme to categorize the narratives of the freshmen and seniors about their future plans. Initial codes evolving from the narratives include "career", "contribution to society", "passing chemistry", "make money", "start a family", "do not want to disappoint family", "travel around the world", "go to graduate school", "start my own business", etc. Emanating from these codes, were four themes. These themes were production, experience, character and relationship. A detailed discussion of these themes as well as examples are given in the Results section. 


\section{The Odyssey Plan Activity}

The Odyssey Plan project helps to show how freshmen and graduating seniors perceive success and how their perception of success shapes the career pathways they choose to pursue upon graduation. For this study, odyssey project assignments were given to two classes during two different academic years at Arizona State University. The first odyssey project assignment was given to a graduating senior class in the fall semester of the 2014-2015 academic year. The same assignment was given to a freshman class in the fall semester of the 2016-2017 academic year. As part of the assignment, students were expected to reflect on their time at Arizona State University, and also map out their plans for the first few years following graduation. They were expected to illustrate this as seasons within an "Odyssey Years Timeframe" template. Figure 1 shows an example of the odyssey years timeframe template students were expected to complete.

\section{Odyssey Years Timeframe}

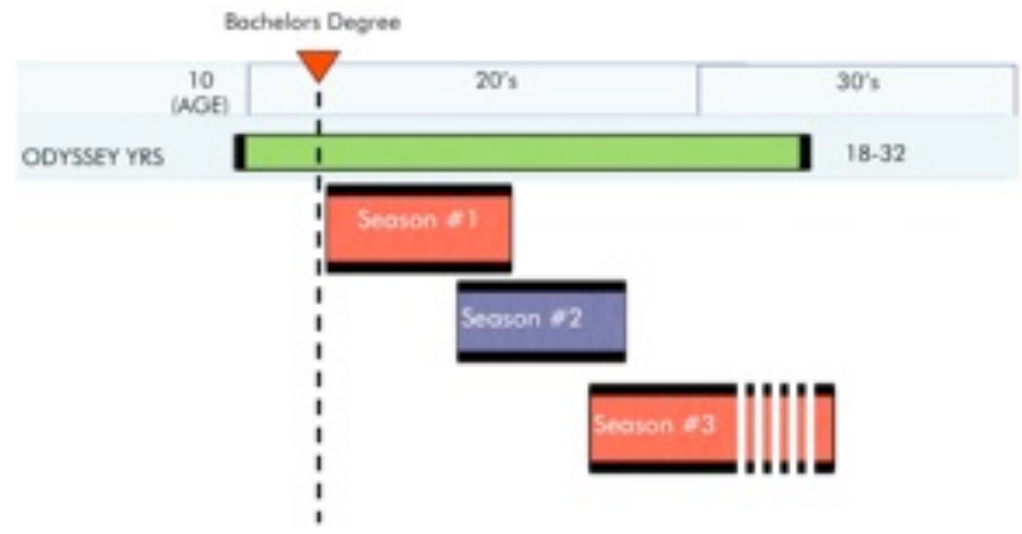

Figure 1: Expected timeframe of odyssey years (from Burnett and Evans 2011)

As students mapped out their plans, a critical component of the project was for students to provide a reason for the pathway they choose. Specifically, they were expected to reflect on their individual plans, and communicate what these plans meant to them (the why) and what outcomes they were specifically pursuing. The outcomes could range from obtaining experience in a particular career, increase income earning potential, networking or professional and personal relationship development or just because everyone expects them to go through that pathway. Students were provided examples such as: Travel for a year, because I want to gain a global point of view, live at home for the next year and try to start up my own company from my parent's garage, or pursue a graduate degree because I want to increase my earning potential.

Furthermore, students were expected to anticipate issues and risks to pursuing their different pathways, while outlining the resources they needed to navigate their preferred pathway successfully. Finally, students were expected to create a graphical representation (dashboard) of their confidence in achieving their plans, judging it either as a full, empty or half full/empty state, as well as represent the level of coherence in their plan on a scale of 0 to $100 \%$. By coherence, students judged how well the plan fit their personality. 


\section{Odyssey Plan Examples}

Freshmen and graduating senior were participated in the odyssey plan project by virtue of enrolling in the freshman introductory class and the professional vision class. The culminating project in the class was the odyssey plan assignment. As part of this assignment, students were expected to present their ten year vision plan on a PowerPoint slide. The first slide required students to represent a ten year vision timeline from their current state. Students were expected to categorize seasons on their ten year plan, and then characterize their expected outcomes for that season. For the freshmen students, the first season was typically their undergraduate years at Arizona State University, while the graduating seniors typically represented graduate school or the first few years on their first jobs. Figure 2 and Figure 3 show example first slide from a freshman student and senior student respectively.

\section{0 year vision timeline}

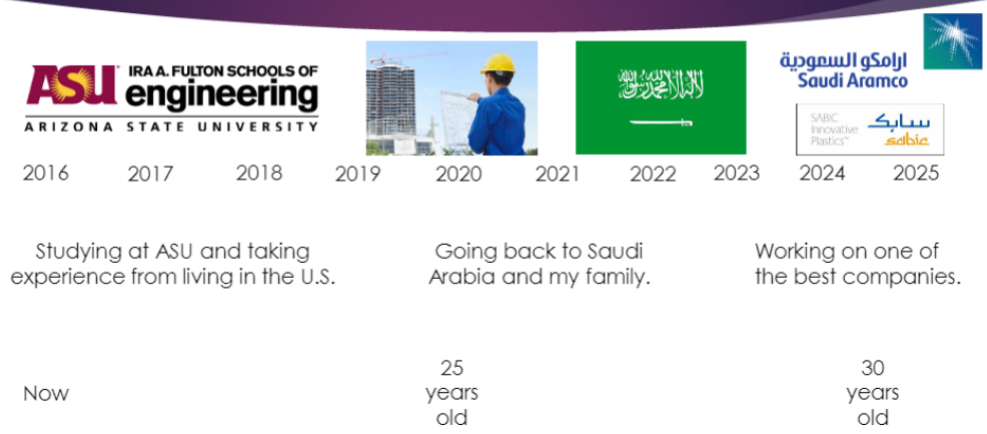

Figure 2: Example first slide of odyssey plan assignment from freshman student

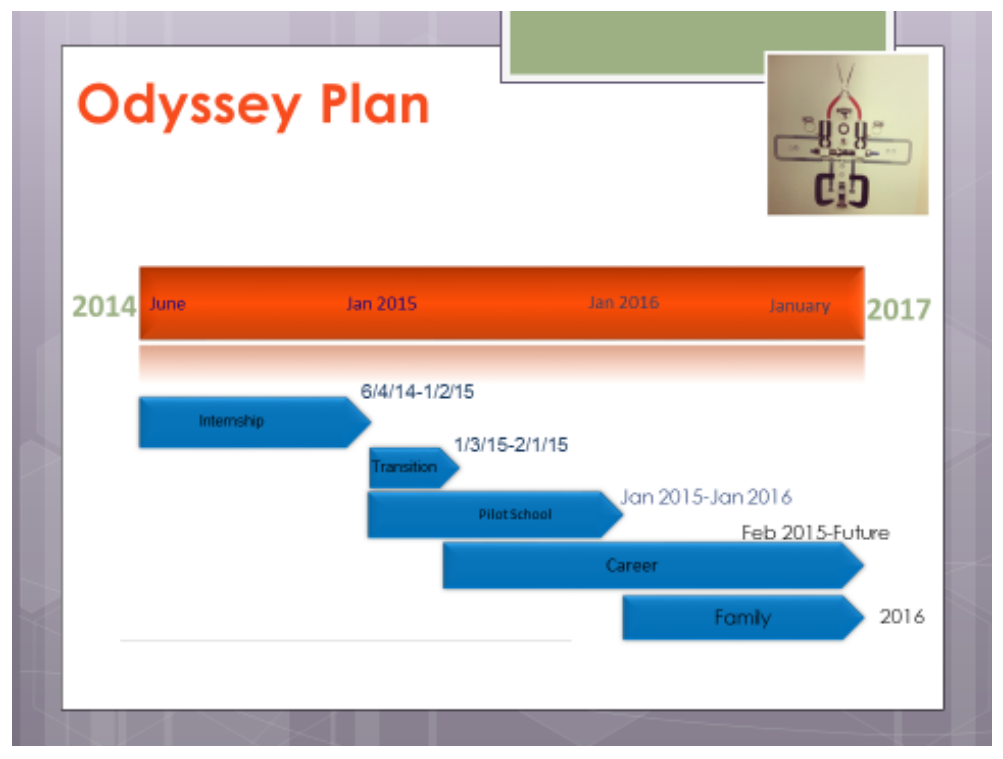

Figure 3: Example first slide of odyssey plan assignment from senior student 
The next three slides were the "prototype" slides were students presented three different ideas on their college and post college plans. Students were at liberty to be creative and were expected to present a description of these plans and the expected outcomes for the plans to be considered successful to them. An example slide of the student's alternate prototype is shown in Figure 4.

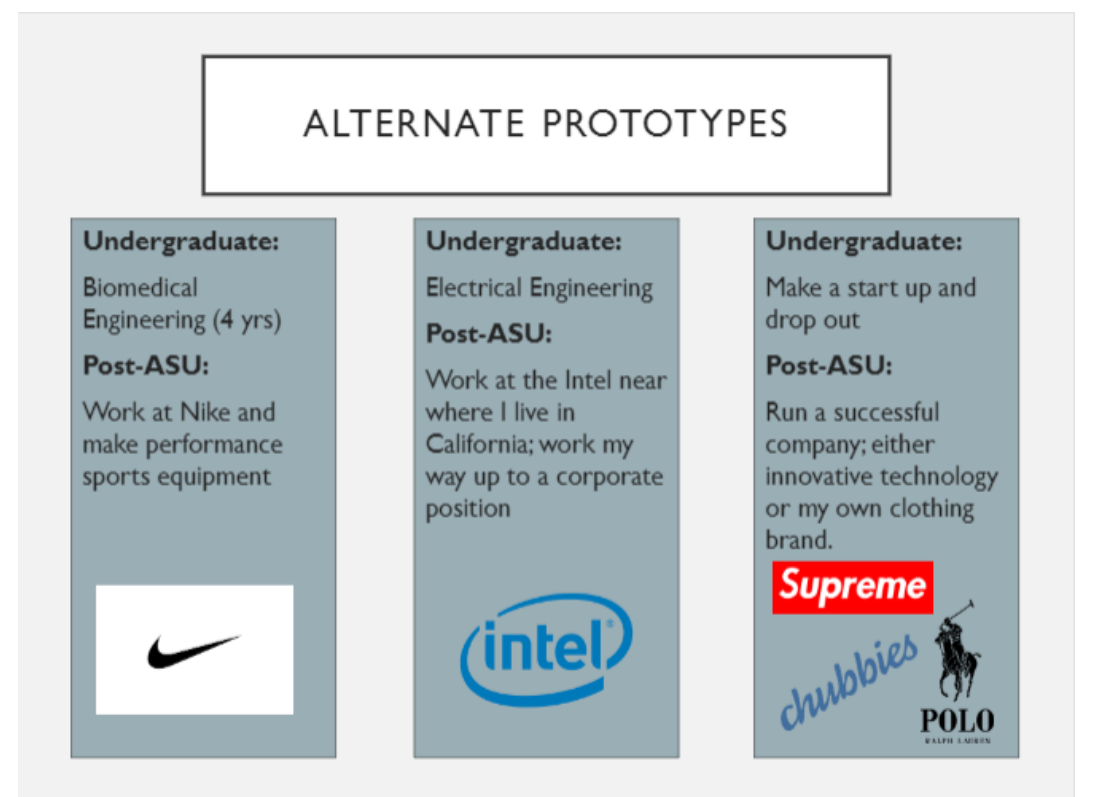

Figure 4: Example slide of student's alternate prototype during and Post College

Finally, the students were expected to present their preferred post college plan and illustrate their plan with a symbol. This symbol was meant to be inspirational to them, and act as a meaningful encouragement in accomplishing the plan. Along with these symbol, students were expected to present an outline of the "why", key issues, desired outcomes and critical support systems needed to accomplish their preferred plan. The final part of the presentation was an opportunity for students to reflect on their plans using four different metrics. They were expected to present the outcome of their reflections in the form of a dashboard. An example dashboard is shown in Figure 5. The four different metrics through which students reflected on their plans were:

1. Resources (0-100\%) - do you have what you need to do this?

2. I Like It (Cold to Hot) - what's your temperature on this plan?

3. Confidence (Empty to Full) - how confident are you in achieving this plan?

4. Coherence $(0-100 \%)$ - how coherent is the plan to who you are as a person, and how coherent is it within and across the elements of the plan itself. 


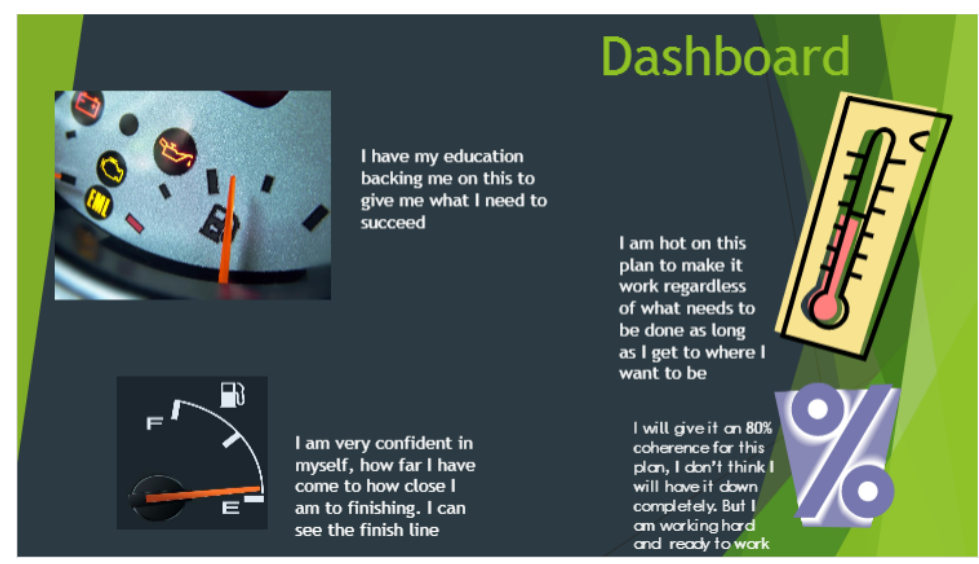

Figure 5: Example slide of student's dashboard

\section{Results: Qualitative Themes and Examples}

The odyssey plan produced by the freshmen students and the graduating seniors at Arizona State University were very similar around the themes of production, experience, character and relationships. Despite the difference in class standings, the perception of success by both groups of students could easily be categorized around these themes.

A lot of the students considered getting a job and starting a career as significant indicators for career success. They associated getting a job to financial independence. The type of job they hoped to seek after graduation was not always in the engineering field. Furthermore, the senior students considered having deep technical competence on the job, as well as networking on the job as significant indicators for career success.

Money also played a key role in loyalty to the job as one student put it "money allows you to assess more opportunities, pays your salary and improves your desire to work. Others included the importance of a comfortable retirement as a symbol of success. The need to "enjoy" career was echoed in the odyssey plans. Students attributed success in their career to enjoying what they were doing. Themes from the odyssey plans created by both the freshmen and senior students are discussed next.

\section{Production Theme}

The production theme in the odyssey project assignment was characterized as the range of options that characterized success for the students, and hence they were interested in pursuing those options post-graduation. Under this category we grouped the contributions of students to society.

The odyssey plans revealed a wide variety of options such as an interest in designing automobiles, working for a space agency, brewing the next category of beer, and being a realtor. There was significant overlap in the options presented by the freshmen students and the graduating seniors. The key take away from the odyssey plans of the students under the 
production theme, was a desire to be contributing members of society. Students clearly articulated why they chose different options and how those options result in them being contributing members of society. Some examples of how students articulated their plans that were coded under the production theme are:

The first off is I'll major in robotics here at ASU. I'll get my degree and go work with some manufacturing company at an engineer role. The second plan is transfer to NAU and get a computer science major. The two benefits to that is my significant other is at NAU, and still get a technical field, which is good. And plan C is to go full-on entrepreneur, and go Elon Musk. For that, you have to have a great idea and a lot of determination, which is difficult, and even so, there's a lot of risk involved.

My third alternative would be to start my own business, which I have experience in because I started my own software business back in high school. And I could keep growing that business.

The three plans that I have, are basically biomedical engineering, and then probably work at Nike and make running shoes or something. Or, major in electrical engineering and then work at Intel, because they have a big headquarters near where I live. So it would be nice to have my career where I've grown up. And then my third plan is make a start-up and drop out of college. With that, it'd either be running a successful company that's innovative technology that I could make a lot of money off of. Or it would be something like designing my own clothing brand or something.

\section{Experience Theme}

Both freshmen and senior students cited the need for experience as a success indicator for their post-graduation plans. We have categorized experience as the process the students take to getting to a state of success in their career. Both freshmen and graduating seniors highlighted the need to immediately get a job after graduating in order to get some experience in their field of study. Outside of getting a job, students were also interested in either starting a business or pursuing a graduate degree and going into research. Some examples of how students articulated these plans coded under the experience theme as given below:

Next year, I'm gonna want to get really into internships so I can get my foot in the door for the job market.

This is the plan, is to follow and become a Civil Engineer, hopefully, or mechanical one. Get $a$ job and then get a better job and then hopefully retire without horribly-getting $a$ horrible brain, degenerative- brain disease is in my family. And second plan, find something I actually like to do and do that instead and just never really stop doing that and maybe make money, but it doesn't really matter if I like doing it, because, you know, if I like doing it, it doesn't really matter. 


\section{Character Theme}

Although all students associated getting a job as a measure of success after graduation, there was a greater purpose that reflected why they needed the job. One of the students reflected on this saying "the point of doing this is to get a job in the robotics (or just plain technology) field. The money is a good incentive too, but I really just want to contribute something to society". The need to impact society was echoed equally by freshmen and senior students. However, the approach to go about making that impact differed from person to person rather than by class standing.

Some students viewed making an impact to society as helping their families. Others saw an opportunity to engage in meaningful research as an alternate approach to influencing society. Furthermore, a third category of students considered philanthropy as the right approach to impacting society. Regardless of the approach each of these students took, it was encouraging to see the next generation of students consider making an impact to society as a lens through which they view success after graduation from their colleges and universities. Some examples of how students articulated these plans coded under the character theme as given below:

And as far as end goals, in terms of this assignment and my life, I want to have a stable future. I want to be able to earn support for my family and those around me.

What's my goal in life? My goal in life is have family and support my parents when they get too old, make my own business. I already closed my junkyard when I came here. I like drifting-I hope, like, I win in a concert or something one day. Make something people will like, such as, like, in the future, if I had a lot of money, I'm thinking to build, like, building, cheap apartment, so they can live for cheap.

\section{Relationships Theme}

All of the students in the freshmen and senior categories referenced the importance of having a family or loved ones as an example of success after graduation. They also referenced the role of these relationships as a necessary support system to continue to achieve success post-graduation. They characterized success around completing their degree programs, getting married and starting a family within the first ten years post-graduation.

\section{Findings}

The thought of coming up with a plan in the first place was a different kind of experience for some students. The opportunity to reflect on prior experiences and pathways, and project possible pathways for the future was a new experience for the seniors and freshmen alike. One student captured this best with his opening slide captioned "Do I really look like a guy with a plan?" Despite this initial apprehension of coming up with a long term plan, the students found the assignment personally rewarding. 
One revelation from the odyssey project was the vast career opportunities that an engineering undergraduate degree provides. Universities and career centers have could potentially use this findings in organizing career exploration fairs for undergraduate engineering students, exposing them to different career opportunities after graduation.

\section{Barriers to Success}

Though all the students anticipated success after graduation in their odyssey plans, they also discussed barriers to this success. The barriers to success could be categorized as intrinsic and extrinsic barriers. The intrinsic barriers were primarily personal factors that students were capable of overcoming with minimal external support, while the extrinsic barriers were typically factors outside of the control of the students.

\section{Intrinsic Barriers}

The most prevalent personal factor students outlined in their odyssey plans as a barrier to their success was personal laziness. This was reflected as a barrier in only the freshman class. We expected this could be due to the first semester shock of being in college without the parental guide that some students had in high school. Another intrinsic barrier that freshmen students were concerned with was passing chemistry. This barrier was so prevalent among the students that an immediate intervention was instituted by the instructor. This intervention involved ad-hoc chemistry study sessions for the freshmen. A majority of the freshmen in this class saw passing chemistry as one of the major hurdles they needed to navigate in order to become an engineer in the future. Below is an excerpt from one student's audio transcript:

If I don't pass Chemistry, I'll get kicked out of the house and I might have to start fending for myself. So I'll get a job, and perhaps if I work for a year, based on my calculations, anyway, if I don't spend my money on anything but food, then I should have more than enough to pay for college.

\section{Extrinsic Barriers}

Money was a factor that was only reflected in the freshmen as an external factor that could potentially prevent their success. The author expected this will not be a factor for graduating seniors as they had already completed their degrees, compared to freshmen who still needed funds for the next three years of their undergraduate degree programs. The most prevalent external factor that both freshmen and senior student mentioned was motivation. Freshmen referenced motivation because they were interested in remaining motivated to finish their degree programs, while seniors cited motivation in order to explore various options after graduation. As expected, seniors referenced other barriers to their success such as job layoffs, outsourcing, and potential world crisis situations like wars. These were not stated as concerns for any of the freshmen students. 


\section{Discussion and Future Work}

Engineering students are directed toward the professions in engineering as a default. The undergraduate engineering curriculum aims to prepare students in technical competencies as well as professional skills towards a career trajectory in STEM. We hope that this work can illustrate more nuanced decisions for students to consider for their post-graduation season of life. Findings from this study will be useful to universities and colleges in understanding how to impact student success during their undergraduate years, as well as improve retention. Companies will also find this information valuable to impact engineers' success and retention in industry.

The odyssey plan project continues to provide students an opportunity to reflect on their pathway to their current state, while planning the next steps of their professional and personal lives. It provides an opportunity for students who may not have previously documented their goals after obtaining an undergraduate degree to consider some viable options that they may be willing to pursue. Inside of the classroom, faculty could use this assignment as a launching pad to exposing undergraduate students to various career opportunities they can be involved with.

Future work on this project will include exploring what success means to undergraduate students in their first year and their senior year. Specifically, understanding what personal metrics and contextual metrics these students use in describing what success means to them will be useful in influencing programs aimed at ensuring students success in colleges and universities.

\section{References}

1. Lent, R. W. (2013). Career-life preparedness: Revisiting career planning and adjustment in the new workplace. The Career Development Quarterly, 61(1), 2-14.

2. Atman, C. J., Sheppard, S. D., Turns, J., Adams, R. S., Fleming, L. N., Stevens, R., Streveler, R. A., Smith, K. A., Miller, R. L., Leifer, L. J., Yasuhara, K., \& Lund, D. (2010). Enabling engineering student success: The final report for the Center for the Advancement of Engineering Education. San Rafael, CA: Morgan \& Claypool Publishers.

3. Arnett, J. J. (2000). Emerging adulthood: A theory of development from the late teens through the twenties. American Psychologist, 55(5), 469-480.

4. Oishi, L. (2012). Enhancing career development agency in emerging adulthood: An intervention using design thinking. Dissertation, Stanford University.

5. Bandura, A. (1989). Human agency in social cognitive theory. American Psychologist, 44(9), $1175-1184$.

6. Brown, T. (2008). Design thinking. Harvard Business Review, 6, 84-92.

7. Reilly, T. (2013). Designing life: Studies of emerging adult development. Dissertation, Stanford University.

8. Burnett, B. and Evans, D. (2016). Designing your life: How to build a well-lived, joyful life. New York City, New York: Knopf.

9. Crotty, M. (2012). The foundations of social research. London: SAGE, 2012.

10. Piaget, J. (1967). Logique et connaissance scientifique [Logic and scientific knowledge]. Dijon, France: Gallimard.

11. Papert, S. (1991). Situating constructionism. In I. Harel \& S. Papert (Eds.) Constructionism. Norwood, NJ: Ablex Publishing.

12. Charmaz, K. (2000). Grounded theory: Objectivist and constructivist methods. In N. Denzin \& Y. Lincoln (Eds.), Handbook of qualitative research (2nd ed., pp. 509-535). Thousand Oaks, CA: Sage.

13. Charmaz, K. (2006). Constructing grounded theory. Thousand Oaks, CA: Sage Publications. 
14. Braun, V., \& Clarke, V. (2006). Using thematic analysis in psychology. Qualitative research in psychology, 3(2), 77-101.

15. Burnett, B. and Evans, D. (2011). Odyssey plans [PowerPoint slides]. From "Designing your life" class presentation. ME104b, Stanford University.

16. Lichtenstein, G., Loshbaugh, H. G., Claar, B., Chen, H. L., Jackson, K., \& Sheppard, S. D. (2009). An engineering major does not (necessarily) an engineer make: Career decision making among undergraduate engineering majors. Journal of Engineering Education, 98(3), 227-234. 